\title{
PERAN PUSAT PELATIHAN PERTANIAN DAN PEDESAAN SWADAYA (P4S) DALAM PENGEMBANGAN PEMUDA PEDESAAN (Studi Kasus di P4S Tani Mandiri Desa Cibodas Kec. Lembang Kab. Bandung Barat)
}

\author{
Iwan Setiawan*, M. Gunardi Djudawinata, Adi Nugraha \\ Departemen Sosial Ekonomi Pertanian Prodi Agribisnis Unpad \\ *iones73@yahoo.com
}

\begin{abstract}
ABSTRAK
Pusat Pelatihan Pertanian dan Pedesaan Swadaya (P4S) merupakan sebuah lembaga yang dibangun, dimiliki dan dikelola secara langsung oleh komunitas petani. Salah satu misi P4S adalah mengembangkan pemuda pedesaan. P4S Tani Mandiri yang berlokasi di Desa Cibodas merupakan satu dari 400 P4S yang menjadi pionir di Indonesia. Hingga tahun 2015, P4S Tani Mandiri telah menghasilkan 1950 lulusan dari seluruh Indonesia. Pertanyaannya, sejauh mana P4S Tani Mandiri berperan dalam mengembangkan (memberdayakan) pemuda di lingkungannya? Tulisan ini bertujuan untuk menganalisis peran P4S dalam pengembangan pemuda dan sejauh mana prinsipprinsip pengembangan masyarakat diterapkan dalam proses tersebut. Data dalam tulisan ini diperolah dari hasil observasi dan wawancara mendalam dengan informan. Hasil analisis mengungkap bahwa selama 20 tahun, P4S Tani Mandiri berperan dalam memberdayakan pemuda pengangguran, memberdayakan anak-anak petani, mengembangkan agribisnis dan menginisiasi usaha-usaha alternatif. Secara umum, prinsip-prinsip pengembangan masyarakat sudah diimplementasikan, namun masih lemah dalam hal menghargai budaya dan sumberdaya lokal, dalam hal ekologis dan belum bersih dari unsur-unsur kolonisasi immateril. Oleh karena itu, perlu dibangun kerjasama dengan komunitas-komunitas hijau dan pelaku-pelaku kreatif yang bergerak dalam perwujudan ramah lingkungan serta peningkatan siklus nilai (value cyclic) dan siklus sumberdaya lokal (resource cyclic).
\end{abstract}

Kata kunci: peran, P4S, pengembangan, pemuda pedesaan

\section{ABSTRACT}

Pusat Pelatihan Pertanian dan Pedesaan Swadaya (P4S) is an institution that is built, owned and managed directly by the farmer community. One of P4S mission is to develop rural youth. P4S Tani Mandiri which located in Cibodas Village is one of P4S pioneers in Indonesia, which has been in succession for 20 years. Until the year of 2015, P4S Tani Mandiri has produced 1950 graduates from all over Indonesia. The question is, how far P4S Tani Mandiri role in developing (empowering) youth in the community? This paper aims to analyze P4S role in the development of youth and the extent to which the principles of community development applied in the process. The data in this paper obtained from observations and interviews with informants in Cibodas. The results of the analysis revealed that for 20 years, P4S Tani Mandiri has contributed to empowering youth unemployment, empowering the children of farmers, developing agribusiness and youth alternative businesses. In general, the principles of community development have been implemented, but still weak in terms of the culture and local resources, in terms of ecological and not yet free from colonization immaterial elements. Therefore, a cooperation with green communities and creative actors engaged in the realization of environmental friendly as well as an increase in the value cycle and the cycle of local resources need to be introduced.

Keywords: role, $P 4 S$, development, rural youth 


\section{PENDAHULUAN}

Pemuda yang digantungi sejuta harapan, baik secara sosial-budaya, tekno-ekonomi, institusi maupun hukum-politik, merupakan sumberdaya pembangunan yang besar, potensial dan strategis. Persoalannya, potensialitas pemuda belum terkelola dan termanfaatkan dengan efektif, terutama di pedesaan. Sebagai catatan, secara statistik, eksistensi pemuda Jabar tahun 2015 mencapai 15 juta atau 36,7 persen dari sekitaar 46 juta jiwa total penduduk. Secara spasial, sekitar 47 persen pemuda Jabar tinggal di pedesaan. Jika porsi pemuda Jabar menurut proyeksi BPS (2010-2020) dirata-ratakan, maka sekitar 36,97 persen (sekitar 13 juta jiwa) penduduk pedesaan adalah kelompok usia 15-34 tahun. Idealnya, pertanian (termasuk perikanan, peternakan) sebagai sektor basis pedesaan dapat menjadi tempat berlabuhnya jutaan pemuda pedesaan. Namun fakta berbicara lain, sebagian dari mereka justru terpental ke perkotaan, sebagian terjun ke sektor informal pedesaan yang jenuh (seperti menjadi tukan ojek, buruh tani), dan sebagian besar "terperosok kedalam kubangan" pengangguran.

Sebagai pendatang baru di kelompok angkatan kerja, pemuda pedesaan dihadapkan pada beragam persoalan. Beberapa faktor penyebabnya adalah lemahnya akses mereka terhadap berbagai sumber daya produktif, seperti lahan, permodalan, pendidikan formal [dan non formal], informasi, teknologi dan lainnya. Selain itu, sebagian besar pemuda pedesaan juga bernaung dalam rumah tangga miskin. BPS (2015) mencatat, dari sekitar 37 juta penduduk miskin di Indonesia, 63,4 \% berada di pedesaan. Sebagai catatan, secara riil, dari total rumah tangga miskin di Jabar, lebih dari $60 \%$ berada di pedesaan. Secara sosio-budaya, sebagai implikasi dari keterbukaan desa terhadap dunia luar, ada kecenderungan pada pemuda pedesaan juga tumbuh kembang perilaku hedonis, manja, apatis, konsumtif dan terjangkiti ragam patologi sosial (Rajab, 2010). Sebagai catatan, dari sekian banyak kasus korban minuman keras dan obat-obatan terlarang yang diberitakan media massa, sebagian besar terjadi di pedesaan dan sebagian besar korbannya adalah pemuda.

Selain itu, sebagian besar pemuda pedesaan juga berstatus penganggur. BPS (2015) menegaskan bahwa dari sekitar 9 juta jiwa angka pengangguran terbuka di Indonesia, sekitar 4 juta jiwa (40\%) merupakan kelompok usia muda (antara 15-34 tahun). Sebagai catatan, jika di Jabar terdapat sekitar 2,26 juta jiwa $(12,28 \%)$, maka 36 persen dari total penduduk Jabar dan 60 persen dari total pemuda Jabar, adalah pemuda pedesaan berstatus penganggur terbuka, termasuk kelompok penganggur terdidik. Ironis, hingga tahun 2015, terdapat sekitar 750 ribu sampai 1 juta sarjana yang menganggur di Indonesia. Sebagian besar dari mereka tinggal di Pulau Jawa dan kota-kota besar di luar pulau Jawa. Angka tersebut jelas belum seberapa jika ditambah pengangguran tidak kentara. Menurut Organisasi Buruh Dunia (ILO) "ledakan penganggur berusia muda kini menjadi ancaman di seluruh dunia, termasuk di Indonesia, karena dari 190,2 juta penganggur di dunia, sebanyak 75,9 juta $(39,9 \%)$ diantaranya berusia 15-24 tahun (kelompok pemuda).

Secara statistik, terjadi penurunan tingkat pengangguran terbuka di Jawa Barat pada Februari 2015 sebesar 0,27 persen dibandingkan dengan periode yang sama tahun 2014 (BPS Jawa Barat, 2015) cukup menggembirakan ditengah "tsunami" krisis ekonomi global. Pertanyaan, apakah penurunan tersebut bersifat permanen atau semu? Secara spasial, apakah penurunan terjadi pula pada kelompok pemuda pengangguran di pedesaan? Jika mencermati lebih dalam pernyataan Kepala BPS Jabar terkait penurunan itu, bahwa peningkatan volume tenaga kerja terbesar terutama terjadi di sektor perdagangan dan jasa, maka sudah dapat diduga bahwa penurunan itu bersifat temporer, bias dan tidak banyak menyentuh kelompok pemuda pengangguran di pedesaan. Penurunan terjadi karena digulirkannya program stimulator (baca: program-program bantuan untuk pemuda) yang instan dan temporer. Itu tidak salah, tetapi patut berhatihati, karena selain tidak berkelanjutan, model pendekatan seperti itu juga menyimpan banyak risiko.

Model pemberdayaan yang dilakukan secara dramatis dengan menjejalkan dan mendesakan mereka, baik melalui pemerataan maupun pembagian kerja dan usaha pada sektor jenuh, baik di perkotaan maupun di pedesaan, memang telah dilakukan. Namun jika meminjam istilah Clifford Geertz, tindakan itu identik dengan berbagi 
kemiskinan (shared poverty) yang sejatinya akan mempercepat laju involusi pada lapangan kerja yang bersangkutan. Itu jelas-jelas tidak kita kehendaki, karena tidak kondusif dan tidak menawarkan jaminan kesejahteraan dan keberlanjutan. Oleh karena itu, agar pemberdayaan positif bagi gerak perubahan sosial dan lingkungan, maka polanya perlu digeser dari pemerataan dan pemadatan lapangan kerja ke diversifikasi dan penciptaan (inovation) lapangan kerja dan wirausaha produktif yang berbasis kerakyatan (plebiscitary). Pertanyaann selanjutnya, bagaimana mewujudkannya?

Memberdayakan pemuda pedesaan jelas membutuhkan kecerdasan, apalagi menghadapi gerak sosial-budaya yang sulit diprediksi dan perilaku politik yang kurang mendidik. Hippocrates mengatakan, sebagai mahluk berakal, pemuda pedesaan tidak hanya mengenali kekuatannya [termasuk potensi sumberdaya lingkungannya], tetapi juga kelemahan dan resep-resep penyembuhnya yang inheren di dalam dirinya. Namun karena pemuda pedesaan "juga manusia" dan mahluk sosial, maka seringkali mengabaikannya. Oleh karena itu, menjadi tugas pemberdaya dalam menginisiasi dan menstimulasi agar pemuda mampu menggunakan kecerdasannya untuk mengeksplorasi potensi dan resep-resep yang inheren dalam dirinya. Memberdayakan pemuda jelas menjadi tanggungjawab semua pihak. Jika mengacu pada UU No. 16 Tahun 2006, maka pihak yang dimaksud adalah penyuluh pemerintah, swasta dan swadaya masyarakat.

Pusat Pelatihan Pertanian dan Pedesaan Swadaya (P4S) merupakan sebuah lembaga pendidikan dan pelatihan pertanian dan pedesaan yang dibangun, dimiliki dan dikelola secara langsung oleh komunitas petani. Sebelum dilembagakan, P4S bermula dari kesuksesan komunitas petani-nelayan dalam mengelola usahataninya hingga terdorong untuk membagi pengalaman dan pengetahuannya kepada sesama petani, baik melalui diskusi, pelatihan sampai magang di lokasi. P4S bertujuan menyelenggarakan program-program pelatihan bagi para petaninelayan di bidang pertanian, perindustrian dan usaha pedesaan secara berkelanjutan. Meskipun P4S terbuka untuk semua petaninelayan, namun sasaran utamanya adalah pemuda tani dan pemuda pedesaan (Departemen Pertanian, 1997).
P4S Tani Mandiri yang berlokasi di Desa Cibodas Kec. Lembang Kab. Bandung Barat merupakan salah satu P4S yang pertama berdiri di Jawa Barat. Secara keseluruhan, di Jawa Barat terdapat 9 P4S dengan spesifikasi komoditas tertentu dan spesifikasi P4S Tani Mandiri sendiri adalah sayuran eksklusif dataran tinggi. Diukur dari tahun awal berdirinya (1993) hingga sekarang (2013), maka P4S Tani Mandiri sudah berumur 20 tahun. Secara kuantitas, sudah ratusan alumni pelatihan dan magang yang dihasilkannya, baik yang berasal dari lingkungan setempat, lingkungan Jawa Barat dan dari luar Provinsi Jawa Barat. Pertanyaannya, sejauhmana peran P4S Tani Mandiri dalam mengembangkan [baca: memberdayakan] pemuda di lingkungan setempat? Secara umum, tulisan ini bertujuan untuk menganalisis peran dari P4S Tani Mandiri dalam memberdayakan pemuda pedesaan yang berada di lingkungannya. Secara khusus, tulisan ini bertujuan untuk: (1) mendeskripsikan dan memetakan proses atau mekanisme dan dampak pengembangan pemuda pedesaan; dan (2) menganalisis penerapan prinsip pengembangan masyarakat dalam pengembangan pemuda pedesaan.

\section{METODE PENELITIAN}

Tulisan ini disusun dari penelitian yang didesain secara kualitatif dengan pendekatan studi kasus (case study) dan teknik wawancara mendalam dengan informan pengelola $\mathrm{P} 4 \mathrm{~S}$ Tani Mandiri dan kroscek dengan informan pemuda tani yang berada di Desa Cibodas. Wawancara dilaksanakan pada bulan Desember 2014. Selain melalui wawancara mendalam, data primer juga dikumpulkan melalui teknik observasi lapangan yang dilakukan secara partisipatif. Data-data yang dikumpulkan dengan menggunakan kerangka $5 \mathrm{~W}$ (what, why, when, where, who ) $1 \mathrm{H}$ (how), kemudian dianalisis secara deskriptif.

\section{HASIL DAN PEMBAHASAN}

Profil P4S Tani Mandiri. P4S Tani Mandiri didirikan sejak tanggal 13 Februari 1993 oleh Ishak (tokoh masyarakat, petani sukses dan KTNA di Cibodas) yang waktu itu baru pulang dari kegiatan magang di Jepang. Selanjutnya Ishak dibantu oleh Tatan Tarjuna (sekretaris), Nina Sutrina (Bendahara) dan para anggota lainnya (Apit Apandi, Amas Juhana, Aca, M.Dimiyati, Tateng dan Robi) yang merangkap sebagai instruktur pelatihan. 
Tujuan pendirin P4S ada lima, yaitu: (1) mengembangkan swadaya petani-nelayan didalam meningkatkan pengetahuan, keterampilan dan wawasan usaha sesama petani-nelayan; (2) meningkatkan keterampilan, kecakapan dan keyakinan petani-nelayan [peserta magang atau pelatihan] terhadap usahatani sebagai pekerjaan atau sumber mata pencaharian; (3) menumbuhkan kreativitas, sikap kritis, rasa percaya diri dan jiwa kewirausahaan petani nelayan peserta magang; (4) meningkatkan keterampilan, kecakapan dan rasa percaya diri petani nelayan peserta magang maupun pengajar; dan (5) menumbuhkan dan mengembangkan hubungan sosial dan interaksi positif antara sesama petani-nelayan.

Kegiatan yang dilakukan P4S adalah: (1) menerima petani-nelayan untuk saling berbagi pengalaman dan meningkatkan pengetahuan dalam semua aspek usahatani; (2) menjadi fasilitator untuk akademisi dalam proses pembelajaran atau pendalaman lapangan; dan (3) melakukan trading, juga sebagai penyangga dalam menjaga keseimbangan harga. Oleh karena itu, P4S yang dikelola secara swadaya terletak dalam lingkungan usahatani milik pengelola dan dilaksanakan dengan beberapa pendekatan (diskusi, pelatihan, percontohan dan magang), baik secara mandiri maupun bekerja sama dengan pihak terkait. Azas yang dianut $\mathrm{P} 4 \mathrm{~S}$ adalah pengembangan usaha, demokrasi, swadaya dan keterpaduan.

Pada awal berdirinya, peserta pelatihan dan magang di P4S Tani Mandiri lebih didominasi oleh petani-petani Cibodas, namun terus berkembang ke lingkup kecamatan, kabupaten, provinsi dan sekarang sudah lingkup nasional. Pada umumnya, peserta pelatihan dan magang di P4S adalah pemuda, baik pemuda tani [praktisi] maupun pelajar (SPMA) dan mahasiswa. Lama mengikuti kegiatan di P4S disesuaikan dengan tujuan dan alokasi waktu yang disepakati, untuk pelatihan rata-rata berkisar antara tiga hari sampai dua minggu, sedangkan lama magang berkisar antara dua minggu sampai tiga bulan. Hingga tahun 2005 alumni P4S Tani Mandiri berjumlah 500 orang, dan tahun 2012 mencapai 1000 orang.

Hasil penelitian Devi (2005) menunjukan bahwa sebagian besar (83\%) peserta pelatihan dan magang di P4S Tani Mandiri adalah pemuda. Mereka adalah 60 persen lulusan $\mathrm{SD} /$ Sederajat dan hanya 35 persen lulusan SMA/Sederajat. Para peserta berlatar belakang petani dan peternak, dengan lama pengalaman 3-10 tahun (65\%). Secara riil, P4S hanya memiliki 6 orang pelatih yang berpengalaman dalam agribisnis sayuran dataran tinggi. Namun, dalam pelaksanaan kegiatan P4S bekerja sama dengan Dinas Pertanian, BBDAH, BPTP, Balitsa, dan lainnya sesuai kebutuhan.

P4S memiliki beberapa sarana prasarana pendukung kegiatan yang memenuhi syarat minimal sebuah P4S, yaitu: (1) memiliki lahan usahatani untuk praktik seluas 3 ha; (2) memiliki tempat menginap bagi peserta berupa 8 buah kamar berukuran $3 \times 4 \mathrm{~m}^{2}$, rumah berukuran $5 \times 7 \mathrm{~m}^{2}$, rumah petani pengelola di sekitar lokasi dan 40 buah alas tidur peserta; (3) memiliki ruangan untuk berkumpul, baik aula untuk pelatihan berukuran $12 \mathrm{~m}^{2}$, maupun gazebo dengan luas $6 \times 8 \mathrm{~m}^{2}$ yang merangkap sekretariat Ikatan Alumni Magang Jepang (Ikamaja); dan (4) memiliki rencana kegiatan belajar tertulis yang disesuaikan dengan materi yang diinginkan oleh peserta pelatihan maupun magang.

Selain itu P4S juga melakukan kombinasi tempat, materi, metode dan sistem penilaian [akreditasi] belajar (di dalam dan di luar ruangan, teori dan praktik, materi terencana dan permintaan peserta, metode ceramah dan partisipatif), Pada umumnya, komposisi materi pelatihan $80 \%$ praktik [peserta turun langsung ke proses produksi sambil belajar sosial dan praktik] dan $20 \%$ teori. Beberapa fasilitas pendukung proses belajar mengajar yang dimiiki P4S Tani Mandiri adalah papan tulis, papan informasi, sekretariat, kamar tidur, lahan praktik, toilet, ruang makan, dapur umum, komputer yang koneks dengan internet, infocus, aula, kursi, lemari dan akses jaringan listrik.

Secara umum, materi pelatihan dan magang yang banyak diterapkan di P4S Tani Mandiri berkaitan dengan tomat hidroponik, kembang kol, brokoli, buncis, kentang, tomat, jamur tiram, stroberi, penanganan pasca panen [shortasi, sterelisasi, pengemasan, grading) hingga pemasaran dan manajemen usaha. Moto pelatihan dan magang adalah "menjadi pengusaha pertanian" dan tema yang diangkat adalah "berbudidaya tanaman sayuran dataran tinggi yang sehat". Sesuai dengan moto dan tema tersebut, materi yang diberikan pada umumnya adalah: budidaya tanaman sayuran dataran tinggi, teknik penggunaan mulsa, 
pengendalian hama terpadu, penggunaan pupuk dan pestisida buatan dan alami, cara menembus pasar modern dan pembelajaran tanah.

P4S Tani Mandiri juga menjalin kerja sama dengan banyak pihak, seperti Ikamaja, BPTP Jawa Barat, Dinas Pertanian Tanaman Pangan dan Hortikultura Kabupaten Bandung Barat dan Provinsi Jawa Barat, perguruan tinggi, supplier dan pasar modern, perusahaan dan lembaga swadaya masyarakat. Mengingat P4S Tani Mandiri menjadi sekretariat bersama Ikamaja, maka banyak jenis dan nama sayuran asal Jepang yang diperkenalkan, dibudidayakan dan dijadikan ikon, seperti mizuna (daun lobak), syungiku (kenikir), cisito (cabai), piman (paprika Jepang), kyuri (mentimun), edamame (kedelai), satsumaimo (ubi jalar), ingen (buncis), nasubi (terung), gobo (semacam ginseng), kaboca (labu), sironegi (bawang daun), horenso (bayam) dan asparagus. Hasil produksi P4S dikelola oleh unit bisnisnya yang berbendera PD Grace, untuk kemudian dipasarkan ke supermarket di Bandung, Jabodetabek, Surabaya dan Denpasar. Bahkan, beberapa diekspor ke Singapura, Taiwan dan Korea Selatan.

Persoalannya, manajemen, organisasi dan kepemimpinan P4S Tani Mandiri yang pada awal berdirinya merupakan kesatuan dengan Asosiasi Prima Segar, Gapoktan Mekar Tani Jaya, PD Grace dan CV Yan's Fruit and Vegetable, tidak regeneratif [bahkan hingga sekarang]. Akibatnya, terjadi kecemburuan sosial, perpecahan dan terbentuk beberapa kelompok. Pertama, P4S Tani Mandiri dan PD Grace [satu keluarga]; Kedua, Gapoktan Mekar Tani Jaya (MTJ) dan membentuk P4S MTJ. Ketiga, kelompok-kelompok usaha mandiri [pecahan dari Yan's Fruit and Vegetable], terutama yang bergerak dalam packing house [supplier sayuran]. Perpecahan tersebut telah mengakibatkan tidak harmonisnya hubungan antara kelompokkelompok yang ada. Meskipun negatif, namun pengurus P4S Tani Mandiri tetap memandang perpecahan tersebut sebagai dinamika kelompok dan merupakan bentuk keberhasilan dari proses pemberdayaan generasi.

\section{Peran P4S dalam Pengembangan}

Pemuda. Peranan (role) merupakan aspek dinamis kedudukan (status) apabila seseorang melaksanakan hak dan kewajibannya sesuai dengan kedudukannya. Peran atau peranan lebih merujuk pada suatu fungsi, penyesuaian diri dan sebagai suatu proses. Menurut Soekanto (1995), peranan menckup tiga aspek: Pertama, meliputi norma-norma yang dihubungkan dengan posisi atau tempat seseorang dalam masyarakat; Kedua, merupakan suatu konsep tentang apa yang dapat dilakukan individu dalam masyarakat sebagai organisasi; dan Ketiga, merupakan perilaku individu yang penting bagi struktur sosial masyarakat. Pada lingkup yang lebih luas, seperti dalam organisasi sebagai kumpulan orang-orang, peran organisasi ketika bersentuhan dengan lingkungan eksternal tidak lagi menjadi peran individu per individu organisasi, tetapi sudah menjadi fungsi kolektivitas, yakni peran institusi atau lembaga (Yustika, 2001).

Pemuda pedesaan, merujuk pada definisi pemuda dari Perserikatan Bangsa-Bangsa (2002), adalah pemuda yang eksis dalam ruang pedesaan yang terjun pada aktivitas pertanian maupun non pertanian yang masuk dalam kelompok umur 15-24 tahun. Pada kenyataan sosial, batasan usia muda sangat bervariasi, ada yang mengelompokan usia 15-30 tahun, usia 15-35 tahun, dan bahkan 15-40 tahun. Batasan yang bervariasi tersebut dipengaruhi oleh variasi kriteria yang digunakan, seperti faktor fisik dan psikolgois. Hal itu menegaskan kepada kita semua bahwa penggunaan batasan pemuda bersifat fleksibel, apalagi dalam organisasi sosial dan politik. Pemuda pedesaan identik dengan pemuda tani, namun konsep ini berdimensi ganda, karena tidak saja dikenakan kepada mereka-mereka yang melakukan kegiatan pertanian (on-farm), tetapi mencakup pula mereka-mereka yang muda yang bergerak pada subsistem pertanian hulu, hilir dan termasuk kelembagaannya. Area pemuda pertanian pun bukan hanya dalam ruang pedesaan, tetapi juga dalam ruang pinggiran kota dan perkotaan.

Pengembangan pemuda pedesaan, khususnya yang berada disekitar P4S, merupakan salah satu program prioritas atau unggulan P4S Tani Mandiri. Pengembangan pemuda yang dimaksud berupa kegiatankegiatan sebagai berikut: (1) memberdayakan pemuda pengangguran, termasuk pemudapemuda sekitar yang pekerjaannya nongkrong dan mabuk-mabukan; (2) memberikan kesempatan kepada anak-anak petani di sekitar untuk magang dan latihan di P4S; dan (3) menciptakan lapangan kerja bagi para pemuda Cibodas yang lemah aksesnya terhadap lahan. 
Pemberdayaan Pemuda Menganggur. Kegiatan memberdayakan pemuda pengangguran dan brandalan dilakukan oleh Bobon [tokoh pemuda, ketua karang taruna dan panggung jawab unit bisnis P4S) melalui pendekatan yang bervariasi, mulai dari ajakan biasa (persuasif) sampai paksaan (represif). Memang tidak mudah memberdayakan kelompok ini, prosesnya harus bertahap. Mulamula yang harus diberdayakan adalah yang paling preman, yang banyak pengikutnya. Pola seperti ini dipandang paling efisien dan efektif, karena jika sukses akan berdampak banyak kepada anggota-anggota atau pengikutnya. Secara teknis, prosesnya mirip dengan penyuluhan, diawali dengan proses penyadaran, tentu harus dilakukan pada saat mereka sedang tidak dalam keadaan mabuk, Para preman diajak diskusi [biasanya di Pos Kamling tempat mereka nongkrong], diberikan penerangan, kemudian diajak jalan-jalan ke ladang atau ke tempat pengemasan hasil panen untuk diyakinkan dan dimotivasi. Jika sudah punya keinginan baru diajak praktik.

Persoalannya, pendekatan yang melelahkan tersebut sebagian besar gagal, tidak mampu membangun kemauan para pemuda brandalan untuk memulai bekerja atau belajar bertani. Ada yang mau, tetapi proporsinya sangat sedikit, dan tidak berlanjut karena terganggu lagi oleh teman-temannya. Namun upaya Bobon dan pengurus P4S tidak turut berhenti. Berbagai metode digunakan, termasuk menurunkan level pendekatan dari cara persuasif ke pendekatan paksaan [bekerja sama dengan pihak Koramil/Babinsa].

Para pemuda dipaksa untuk mulai berusahatani. Mereka ditongkrongi setiap hari, diberi makan dan rokok gratis, dilatih secara partisipatif. Pokoknya mereka dipaksa untuk mencangkul. Mencangkul merupakan strategi mencuci ketergantungan pada minuman dan obat-obatan. Mencangkul dapat menggerakan seluruh anggota badan, mengencangkan otot dan menguras keringat, sehingga perlahan kecanduannya terhadap minuman keras atau obat terlarang akan hilang dengan sendirinya. Lebih dari itu, para preman juga menjadi terampil dalam memulai budidaya sayuran.

Kunci keberhasilan pendekatan ini adalah kesabaran dan konsistensi dari kita (dari fasilitator) untuk terus mengawal dan meyakinkan mereka. Pertama, agar mereka yakin dan percaya kepada apa yang kita upayakan; dan Kedua, agar mereka tidak terganggu dan diganggu oleh teman-temannya yang masih keluyuran. Memberdayakan pemuda brandalan memang memakan waktu yang cukup lama, bahkan sampai tahunan. Tetapi ketika salah satu tokoh preman sudah berhasil diberdayakan dan menjadi pengusaha sayuran (bahkan ada yang sukses menjadi supplier) di Cibodas, maka upaya selanjutnya relatif lebih ringan. Si preman yang eling jauh lebih sukses dalam membujuk para preman lainnya untuk berusahatani dan berusaha pada subsistem agribisnis lainnya. Bahkan, ada beberapa preman yang saking berterima kasih kepada kita (pengurus P4S, terutama Bobon dan Ishak), sampai sekarang pun masih bekerja di P4S, meskipun mereka memiliki usaha.

Sejak memulai memberdayakan para preman tahun 1999 hingga tahun 2005 Bobon bersama karang taruna Desa Cibodas dan pengurus P4S Tani Mandiri lainnya telah berhasil memberdayakan hampir 95 persen pemuda brandalan. Pada kenyataannya, para pemuda yang berhasil diberdayakan tidak semuanya bekerja dan berwirausaha pada usahatani sayuran dataran tinggi, selain akses lahan sebagian besar dari mereka lemah, juga disesuaikan dengan minat dan bakatnya. Beberapa dari mereka ada yang bertani, ada yang bekerja di pemasok (supplier), ada yang bekerja di P4S, ada yang sopir, ada yang menjadi pedagang pengumpul, ada yang menjadi supplier, ada yang menjadi penyedia sarana produksi pertanian dan ada juga yang sukses sampai ikut magang ke Jepang dan kemudian menjadi instruktur dan supplier. Keberhasilan Bobon dan pihak terkait lainnya dalam memberdayakan dan menyelesaikan persoalan sosial tersebut kemudian mendapat penghargaan dari pemerintah, dan dalam perjalanannya kemudian, kisah sukses tersebut difilmkan oleh salah satu station televisi nasional (Trans TV).

\section{Pemberdayaan Generasi Petani.}

Pendekatan pemberdayaan yang kedua adalah program pelatihan dan magang bagi anak-anak petani [petani muda] di P4S Tani Mandiri. Program ini dapat dikatakan sebagai upaya nyata para petani Desa Cibodas (khususnya) dan Lembang (umumnya) dalam melakukan regenerasi. Implementasinya dilakukan melalui kerjasama dengan para pengurus kelompok tani, pemerintah desa, pemerintah kecamatan (terutama dengan penyuluh) dan Ikamaja (Gambar 2). Proses pendidikan, pelatihan dan magang yang diterapkan kepada petani muda 
pada prinsipnya tetap sama dengan apa yang telah diprogramkan di P4S. Jumlahnya berkisar antara 3-5 orang dalam setiap angkatan. Kenapa tidak banyak? Karena menurut Ishak, kalau banyak tidak efektif. Pengalaman tahun 2008 merekrut 35 orang petani Cibodas dan Suntenjaya, ternyata lebih dari separuhnya mengudurkan diri.

Berangkat dari pengalaman, maka tanggungjawab seleksi diserahkan kepada pengurus kelompok tani dan pemerintah desa. Sebenarnya, P4S terbuka bagi siapapun petani Lembang yang mau magang, namun khusus untuk regenerasi, peserta dibatasi usia antara 15-24 tahun. Pendidikan juga tidak dibatasi, dari mulai SD sampai Sarjana. Khusus untuk pelatihan petani muda Lembang, tempat praktik tidak hanya di $\mathrm{P} 4 \mathrm{~S}$, tetapi juga di lahan pertanian tempat mereka (kerja sama dengan kelompok tani). Latar belakang peserta juga tidak dibatasi, terpenting memiliki kemauan untuk menjadi petani. Ishak mengatakan, tahun 2005 P4S pernah bekerja sama dengan UNINUS untuk memberdayakan buruh tani, tukan ngarit dan tukan ojek, namun ditengah jalan mereka kabur semua, karena sibuk dengan pekerjaannya masing-masing. Belajar dari pengalaman itu, selanjutnya kami melakukan seleksi dan kontrak, baik langsung maupun tidak langsung.

Kecenderungannya, tingkat pendidikan lebih dominan dijadikan dasar untuk seleksi pelatihan. Hal ini dilakukan karena berdasarkan pengalaman menunjukan, semakin rendah tingkat pendidikan, semakin rendah motivasi untuk berlatih secara sungguhsungguh. Ishak dan Bobon mengatakan "peserta yang berpendidikan STM/SMU/SMK dan perguruan tinggi itu lebih menunjukkan keingintahuan yang tinggi, kecenderungannya mereka semakin lama mengikuti pelatihan dan magang, semakin ingin memperbanyak pengetahuan yang didapat, dan tidak jarang mereka mencari informasi ke luar kelas pelatihan, misalnya mendatangi petani-petani sekitar P4S". Sayangnya, proporsi petani muda Lembang yang berpendidikan tinggi kurang dari $10 \%$. Selain itu, peserta yang serius biasanya sudah memiliki pengalaman usahatani, sehingga niatnya benar-benar ingin meningkatkan pengalamanannya.

Para pengelola P4S menyadari bahwa akses pemuda terhadap lahan semakin sulit, apalagi dengan tingkat alih fungsi lahan yang tinggi dan pemusatan penguasaan lahan pada segelintir elit. Oleh karena itu, dan sesuai dengan peran dan fungsi P4S, maka materi pelatihan untuk pemuda tidak hanya usahatani komoditas tertentu, tetapi juga materi agribisnis lainnya, baik dalam penyediaan input produksi, penanganan pasca panen, pemasaran hasil dan pengelolaan kelembagaan. Harapannya, kelak ketika telah selesai pelatihan, keterlibatan mereka dalam dunia pertanian tidak membuat pertanian semakin tertekan (istilah Geertz, tidak mempertajam involusi pertanian), tidak mempersempit skala usahatani. Artinya, para pemuda tani lebih didorong pada wirausaha agribisnis non usahatani, terutama peningkatan rantai nilai (value chain), distribusi dan rantai pasokan (supply chain).

Penerapan pendekatan agribisnis bukan hanya diprogramkan secara latah oleh $\mathrm{P} 4 \mathrm{~S}$, tetapi juga didasarkan atas pengalaman, Menurut Doni, pernah pada suatu waktu ada beberapa peserta magang setempat yang ketika pulang langsung meminta lahan garapan kepada orang tuanya untuk memulai usaha, orang tua tentu senang dan menyambut baik semangat anaknya, tetapi persoalannya, orang tua menjadi kehilangan mata pencaharian, apalagi si anak sudah berumah tangga". Hal seperti itu jelas tidak kami inginkan, itulah sebabnya kami lebih mendorong pemuda tani pada subsistem yang berada di luar usahatani, yang selama ini lebih banyak dikendalikan oleh pelaku bisnis dari luar desa atau luar kecamatan Lembang. Selain itu, khusus untuk peserta yang berprestasi dan potensial, kami memberikan kesempatan kepada mereka untuk magang ke Jepang. Hampir dipastikan, dalam setiap tiga tahun sekali, ada petani muda Lembang terseleksi (alumni pelatihan P4S) yang mengikuti program magang ke Jepang.

Pada umumnya, berdasarkan pemantauan pengurus $\mathrm{P} 4 \mathrm{~S}$, para alumni pelatihan mampu berbisnis lebih serius, lebih beragam dan lebih berkualitas, baik dalam bidang usahatani, pemasaran, pengelolaan kelompok, pengemasan [packing hous] maupun agroindustri, Ishak menyadari bahwa pengurus $\mathrm{P} 4 \mathrm{~S}$ sangat terbatas dalam menciptakan kreasi usaha baru bagi para peserta, oleh karena itu menjalin kerja sama dengan berbagai pihak untuk mendapatkan inovasi wirausaha yang lebih prospektif. Ada kekhawatiran, dan bahkan sudah terjadi, persaingan yang ketat dalam bisnis sayuran tidak hanya terjadi dalam usahatani [involusi], 
tetapi juga dalam pemasaran hasil dan penyediaan input produksi. Menurut Ishak, supplier saja sudah berlebih, Apalagi dengan banyaknya pemain dari luar Lembang, semakin memperketat persaingan. Buktinya, beberapa packing house dan supplier sudah gulung tikar.

Inovasi Lapangan Kerja Alternatif. Seperti telah disinggung sebelumnya bahwa beban lahan pertanian di Cibodas sudah sangat berat, selain karena jumlah penduduk semakin tinggi, juga alih fungsi lahan yang tidak terhindarkan, baik ke pemukiman maupun peruntukan lain yang lebih besar.

Implikasinya, akses terhadap lahan semakin sulit, harga lahan semakin mahal, penguasaan oleh orang luar semakin meningkat dan dominasi lahan oleh segelintir petani elit semakin tajam. Akibatnya, pada tingkat rumah tangga, involusi pertanian tidak terhindarkan. Bahkan, sejak tahun 2000, di Desa Cibodas sudah jarang terdengar relasi penyakapan atau maro, yang ada adalah sewa (land-rent). Sejatinya, involusi pertanian tidak hanya terjadi pada lahan, tetapi juga pada aktivitas non lahan, termasuk lapangan kerja dan usaha (Gambar 3).

Para pengurus $\mathrm{P} 4 \mathrm{~S}$ menyadari bahwa usahatani sayuran di Desa Cibodas dapat dikatakan sudah jenuh. Sudah tidak dapat lagi menampung angkatan kerja baru, sudah tidak mampu menampung pelaku usaha baru, termasuk pelaku pemasarannya. Boleh jadi, jumlah pedagang pengumpul, bandar, packing house dan supplier yang berbisnis di Desa Cibodas mencapai sepertiga dari jumlah petaninya. Implikasinya, terjadi persaingan tidak sehat, dan saling menjatuhkan antar pelaku pasar. Faktanya, tidak sedikit bandar, pengumpul dan supplier yang bangkrut. Tentu bukan karena itu saja, tetapi hal itu cukup menggambarkan bahwa persaingan dalam bisnis sayuran sudah jenuh. Kejenuhan kelembagaan sejatinya hanya melanjutkan kejenuhan pada lahan, pada kelompok tani, dan pada komoditas. Benar bahwa inovasi usaha, terutama dengan hadirnya komoditas sayuran ekslusif yang berharga tinggi, mampu menjadi solusi atas sempitnya skala usaha, namun faktanya tidak seluruh petani memiliki peluang untuk mengusahakannya, disamping pasarnya yang terbatas.

Berangkat dari keadaan tersebut, para pengurus P4S melalui pendekatan sistem agribisnis, mulai mengembangkan materi dan cakupan kegiatan pelatihan dan magangnya pada pendekatan yang lebih luas, yakni diversifikasi vertikal dan horizontal untuk ragam komoditas dan pendekatan sistem agroforestri. Para pemuda tani tidak lagi dilatih dalam aspek agribisnis sayuran saja, tetapi juga keterampilan bidang wirausaha peternakan dan agroindustrinya, penguatan kepemimpinan dan kapasitas pengelolaan institusi, agrowisata, pengembagan tanaman rempah/obat-obatan, dan sistem agroforestri. Implementasinya dilakukan melalui kerja sama dengan sesama P4S, kelompok tani, dinas terkait, balai penelitian terkait dan perguruan tinggi. Bahkan, untuk pengembangan peternakan, P4S Tani Mandiri bekerja sama dengan P4S yang khusus menangani peternakan. Praktinya dilakukan melalui pertukaran peserta magang antar P4S. Materi dan praktik peternakan tidak hanya sebatas budidaya, tetapi sampai pada pengolahan hasil dan pengolahan kotorannya. Misalnya, untuk sapi perah, materi pelatihan sampai pada pengolahan susu menjadi beragam produk dan pengolahan kotorannya menjadi pupuk organik.

Inovasi yang diterapkan oleh P4S Tani Mandiri memang baru dimulai tahun 2008, tetapi beberapa alumninya [pemuda sekitar, maupun dari luar] sudah banyak yang berhasil mengembangkan peternakan kelinci, sapi perah dan domba. Beberapa alumni perempuan ada yang mengembangkan keripik sayuran, dan pengolahan susu sapi. Beberapa yang lain sudah sukses menjadi peternak dan produsen pupuk organik. Beberapa alumninya juga bergabung membangun unit bisnis bersama, mulai dari usaha stroberi dan aneka bunga, sampai bisnis rumput [pakan] dan penggemukan sapi. Bisnis rumput merupakan salah satu produk pelatihan agroforestri, disamping peternakan terpadu (sylvopastoral). Beberapa alumni P4S juga bergerak dalam pengembangan sayuran, buah-buahan dan peternakan organik.

Persoalannya, pemberdayaan pemuda pengangguran pedesaan oleh P4S Tani Mandiri tidak berjalan secara berkelanjutan. Prosesnya hanya efektif dan intensif pada beberapa tahun program, terutama ketika belum terjadi perpecahan antar anggota dan pengurus. Selain itu, pada perkembangan selanjutnya, P4S lebih sibuk dengan mengelola peserta magang [para pemuda] dari luar desa, bahkan dari provinsi lain. Isu tentang semakin 
komersialnya P4S dibantah oleh pengurus, menurut mereka ada dua faktor yang menyebabkan melemahnya upaya pemberdayaan pemuda pedesaan. Pertama, sudah banyak pemuda yang berdaya [sukses] sehingga mampu secara mandiri memberdayakan pemuda pedesaan; dan Kedua, pemberdayaan pemuda sudah ditangani oleh kelompok-kelompok mandiri, termasuk oleh P4S baru.

\section{Aplikasi Prinsip CD dalam} Pengembangan Pemuda. Barker (1995), menjelaskan bahwa konsep pemberdayaan dalam diskursus pembangunan masyarakat selalu dihubungkan dengan konsep mandiri (self-help), partisipasi, jaringan kerja, dan keadilan. Pada dasarnya, pemberdayaan diletakan pada kekuatan tingkat individu, kelompok (group), komunitas dan institusi (termasuk organisasi sosial ekonomi). Sedangkan Putnam (2001), mendudukan pemberdayaan berdasarkan perspektif sosiologi ekonomi, yakni menampilkan peranperan aktif (partisipatif), saling percaya (trust), jejaring (network) dan kerja sama (collaboration) antara masyarakat dan relasinya. Merujuk pada definisi power, Craig dan Mayo (1995) menyatakan, jika keadaannya seperti itu, istilah pemberdayaan yang disamakan dengan power harus dinegosiasikan sebagai strategi untuk mengadakan reformasi sosial.

Secara umum, proses pengembangan pemuda pedesaan dapat dilakukan dengan mengacu kepada prinsip pengembangan masyarakat (Community Development/CD), yakni: (1) ekologis, yang mencakup holisme, berkelanjutan, keanekaragaman, perkembangan organic, perkembangan yang seimbang, prinsip-prinsip, keadilan sosial dan HAM, mengatasi struktur yang merugikan, mengatasi wacana-wacana yang merugikan, pemberdayaan, hak asazi manusia dan definisi kebutuhan; (2) menghargai pengetahuan local, meliputi menghargai budaya local, menghargai sumber daya local, menghargai keterampilan masyarakat local, menghargai proses lokal dan partisipasi; (3) proses, meliputi proses, hasil dan visi, integritas proses, penumbuhan kesadaran, partisipasi, kerjasama, consensus, langkah pembangunan, perdamian dan anti kekerasan, inklusivitas, dan membangun masyarakat; dan (4) global dan lokal, meliputi keterkaitan global dan local, dan anti praktek kolonialisme (Jim Ife, 2002).
Berdasarkan hasil wawancara mendalam dan observasi di lapangan terungkap bahwa tidak semua prinsip pengembangan masyarakat diimplementasikan dalam pengembangan pemuda. Sebagai P4S yang diberi mandat untuk mengembangkan agribisnis sayuran, P4S Tani Mandiri masih dihadapkan pada kondisi yang dilematis antara tuntutan usahatani sayuran yang responsif terhadap input-input kimia dan intensif, dengan tuntutan ramah lingkungan. Ishak mengakui bahwa upaya-upaya menerapkan prinsip ekologis sedang diupayakan, tetapi dalam usahatani sayuran implementasinya masih minim. Apa yang diberikan kepada para pemuda dalam proses pelatihan maupun magang masih didominasi oleh pendekatan usahatani yang tidak ramah lingkungan. Efek input kimia memang disampaikan, tetapi praktiknya masih padat input kimia, terutama dalam sistem hidroponik. Pendekatan berwawasan lingkungan baru dirintis pada peserta pelatihan dua angkatan terakhir, seperti pertanian organik, usaha pupuk organik, pendekatan diversifikasi komoditas, pengembangan peternakan terpadu, penggunaan pupuk berimbang dan pendekatan agroforestri. Salah satu komoditas yang dikembangkan secara organik adalah jagung Jepang.

Sebagai lembaga yang berakar dari swadaya masyarakat, terutama petani-petani maju, upaya-upaya untuk memberdayakan pemuda Desa Cibodas dan sekitarnya merupakan salah satu bentuk tangung jawab sosial kepada lingkungan sekitar. Secara umum, prinsip-prinsip keadilansosial dan hak asasi manusia sudah diimplementasikan oleh P4S, terutama dalam pengembangan pemuda desa. Sebagai catatan, memberdayakan para pemuda pengangguran yang sering meresahkan warga merupakan salah satu bentuk konkrit dari upaya mengatasi struktur yang merugikan. Bahkan, secara tegas, $\mathrm{P} 4 \mathrm{~S}$ sendiri berperan sebagai penyangga (buffer) terhadap tekanan pasar. Upaya-upaya P4S dalam memecahkan masalah ketimpangan generasi (aging agriculture) dan masalah kejenuhan sektor usahatani sayuran merupakan salah satu bentuk mengatasi struktur dan wacana-wacana yang merugikan. Pemberdayaan merupakan peran dan fungsi utama P4S, dan melibatkan masyarakat sekitar merupakan bentuk penghargaan terhadap hak asasi manusia. Penyesuaian materi pelatihan dengan kebutuhan peserta pelatihan juga 
merupakan bentuk akomodatif P4S dalam mendefinisikan kebutuhan. Mungkin yang masih belum diimplementasikan dalam aspek hak asasi manusia dan definisi kebutuhan adalah penggunaan input-input kimia yang dapat membahayakan kesehatan konsumen.

Hal yang belum terlihat adalah menghargai budaya lokal terkait dengan budaya tani. Dalam proses pelatihan dan magang, para pemuda lebih banyak diberikan gambaran tentang kesuksesan pertanian dan petani di Jepang. Bukan hanya itu, para pemuda juga diperkenalkan dengan berbagai jenis sayuran yang berasal dari Jepang, dengan nama-nama yang juga menggunakan bahasa Jepang. Sepertinya budaya bertani Jepang diadopsi dan diperkenalkan sebagai superior, sementarara budaya pertanian lokal ditempatkan sebagai yang imferior. Memang didalam proses pelatihan dan magang kebutuhan peserta diakomodir, tetapi ketika masuk dalam proses dan lingkungan praktik yang serba didesain dengan aksesoris yang serba Jepang, nilai dan proses lokal menjadi tereduksi kembali. Memang tidak salah peserta diperkenalkan dengan bahasa Jepang, apalagi dengan tujuan untuk merangsang peserta agar berusaha untuk dapat lolos magang ke Jepang, tetapi istilah-istilah lokalnya juga jangan dihilangkan. Mungkin hanya partisipasi yang dapat diberi poin positif dalam proses pelatihan dan magang di P4S Tani Mandiri.

Secara normatif maupun praktik, $\mathrm{P} 4 \mathrm{~S}$ Tani Mandiri telah menerapkan prinsip-prinsip proses dalam pengembangan pemuda pedesaan. Bahkan, hampir seluruh prinsip teridentifikasi positif di wujudkan oleh P4S. Proses merupakan hal yang paling dikedepankan dalam mewujudkan peserta pelatihan dan magang, semuanya harus melalui proses, tidak memberikan sesuatu yang instan, terutama dalam mengembangkan pemuda brandalan. P4S memiliki prinsip, yang penting jalani saja dulu, hasil nanati akan mengikuti. Tetapi dalam proses, para peserta dibangun mental dan pandangannya untuk menjadi pengusaha agribisnis, bukan petani kelas teri. Penumbuhan kesadaran merupakan tindakan pertama yang dilakukan P4S dalam mengembangan pemuda pedesaan, karena tanpa kesadaran apa yang akan dijalankan tidak akan efektif. Adapaun penggunaan pendekatan represif pada kelompok pemuda brandalan, itu sebuah pengecualian.

Partisipasi, kerjasama dan konsensus dibangun secara bersama, baik pada saat proses, maupun pasca proses [ada ikatan alumni magang P4S Tani Mandiri]. P4S terbuka untuk umum, tidak dibatasi usia, umur, jenis kelamin, latar belakang, suku, ras dan agama. Peserta dari manapun diberi pelayanan yang sama, tetapi tetap menjunjung norma dan etika.

Keberadaan P4S Tani Mandiri tidak dapat dilepaskan dari komunitas IKAMAJA. Tentu bukan karena sekretariat P4S berada dalam satu payung dengan IKAMAJA, tetapi lebih karena P4S menjadi mediator yang banyak mengirimkan dan menghasilkan peserta magang ke Jepang. Pada umumnya, para pengurus P4S Tani Mandiri merupakan alumni-alumni magang Jepang. Oleh karena itu, terkait dengan prinsip global dan lokal, P4S sudah menerapkannya secara kelembagaan, tetapi belum secara ekologis. Meskipun tidak sering, P4S Tani Mandiri juga memiliki relasi dengan pelaku-pelaku kebijakan dan pelaku agribisnis global, terutama dari Jepang dan FAO. Secara kelembagaan, P4S Tani Mandiri pernah sukses mengekspor beberapa komoditas andalannya ke Korea Selatan, Taiwan dan Singapura. Sebagai institusi ekonomi-politik, P4S anti kolonial, tetapi secara simbolik P4S Tani Mandiri belum bebas dari kolonisasi immateril. Bahkan, tidak juga steril dari intervensi negara dan entitas politik.

\section{KESIMPULAN}

P4S Tani Mandiri berperan dalam mengembangkan pemuda tani, baik pemuda Desa Cibodas dan desa-desa sekitar Lembang, maupun lingkup yang lebih luas. Wujud konkritnya adalah pemberdayaan pemuda pengangguran, pengembangan pemuda tani sebagai upaya regenerasi dan pengembangan usaha-usaha alternatif yang lebih berwawasan lingkungan. Secara umum, prinsip-prinsip pengembangan masyarakat teridentifikasi telah diimplementasikan di P4S Tani Mandiri, tentu dengan derajat yang bervariasi. Prinsip yang tergolong masih lemah implementasinya adalah prinsip menghargai budaya dan sumberdaya lokal, serta prinsip ekologis [pertanian ramah lingkungan]. Keadaan tersebut berimplikasi pada lemahnya upaya P4S dalam penegakan prinsip bersih dari unsur kolonisasi, terutama kolonisasi immateril.

Bagi pengembangan usaha alternatif [non sayuran], P4S Tani Mandiri hendaknya menjalin kerja sama dengan komunitas kreatif 
di Jawa Barat. Secara sosiologis, mengubah perilaku masyarakat yang berbudaya sayuran ke usaha non sayuran juga tidak gampang, oleh karena itu, pemerintah hendaknya mendorong tenaga terdidik terampil dan berkeahlian untuk menginisiasi dan memfasilitasnya. P4S dapat memanfaatkan jaringan sosial dan jaringan internet untuk mengembangkan inovasi wirausaha pedesaan, atau memberdayakan wirausaha muda alternatif yang sudah berjalan yang ada di desa. Pendekatan internalisasi memungkinkan lebih menjamin keberlanjutan daripada institusionalisasi, termasuk dalam membudayakan nilai lokal dan menghargai sumberdaya lokal sebagai prasyarat untuk dapat lepas dari kolonisasi immateril.

\section{DAFTAR PUSTAKA}

Badan Pusat Statistik. 2007. Indonesia dalam Angka: Data Angkatan Kerja. Badan Pusat Statistik Indonesia, Jakarta

Badan Pusat Statistik. 2008. Jawa Barat dalam Angka: Data Angkatan Kerja Daerah Jawa Barat. Badan Pusat Statistik Jawa Barat, Bandung

CCMA. 2005. Youth Development. http:///ccmacanada.org

Craig, G. dan M. Mayo. 1995. Community Empowerment. A Reader in Participation and Development. Zed Books, London and New Jersey.

Departemen Pertanian. 1997. Profil Pusat Pelatihan Pertanian dan Pedesaan
Swadaya (P4S). Badang Pendidikan dan Pelatihan Pertanian Departemen Pertanian, Jakarta.

FAO, ILO and UNESCO.2009. Training and Employment Opportunities to Address Poverty Among Rural Youth: A Syntesis Report. FAO, ILO and UNESCO, Bangkok Thailand.

Jim Ife. 2002. Community Development: Community-Based Alternatives in an Age of Globalisation. Second Edition. Pearson Education Australia Pty Limited.

Pemerintahan Desa Cibodas. 2011. Monografi Desa Cibodas. Pemerintahan Desa Cibodas, Lembang Kabupaten Bandung Barat.

Pranaka dan Vidhyandika. 1996. Pemberdayaan dalam Onny S.P dan

A.M.W. Pranaka (ed). 1996. Pemberdayaan: Konsep, Kebijakan dan Implementasi. CSIS, Jakarta.

Rajab, B. 1995. Koraban-Korban Pembangunan. Prakarsa Edisi November 1996 - Bandung: Pusat Dinamika Pembangunan Unpad.

Ritzer, George. 1988. Sosiologi, Ilmu Pengetahuan Berparadigma Ganda. Terjemaahan. Rajawali Press, Jakarta. Soekanto. S. 1995. Sosiologi Suatu Pengantar. Edisi Revisi. Radjawali Press, Jakarta

Stewart, A.M. 1998. Empowering People: Pemberdayaan Sumberdaya Manusia. Penerbit Kanisius, Yogyakarta. 